ESSAY

\title{
The Respect Wildlife Campaign: A collaborative effort to reduce human disturbance to California's coastal wildlife
}

\author{
NICOLE B. TURNER ${ }^{1}$, GENA B. BENTALL ${ }^{2}$, COLLEEN YOUNG ${ }^{3 *}$, \\ ANDREW B. JOHNSON ${ }^{4}$, WILLIAM G. STANDLEY ${ }^{5}$
}

${ }^{1}$ National Park Service, 1201 Oakridge Dr., Fort Collins, CO 80525, USA

${ }^{2}$ Sea Otter Savvy, 1961 Main St. 199, Watsonville, CA 95076, USA

${ }^{3}$ California Department of Fish and Wildlife, Marine Wildlife Veterinary Care and Research Center, 151 McAllister Way, Santa Cruz, CA 95060, USA

${ }^{4}$ Defenders of Wildlife, 762 Laurel Avenue, Pacific Grove, CA 93950, USA

${ }^{5}$ Bureau of Land Management, California Coastal National Monument, 940 2nd Ave, Marina, CA 93933, USA

*Corresponding Author: colleen.young@wildlife.ca.gov

Key words: behavior change, campaign, collaboration, ecotourism, human disturbance, outreach, wildlife

A form of nature-based tourism known as ecotourism is an immense and burgeoning industry (Bowker et al. 2012; Balmford et al. 2015; Murray et al. 2019). For a time, the boon of ecotourism seemed an irreproachable alternative to the extractive exploitation of wildlife, and many communities derived benefits by preserving living, thriving natural areas and encouraging tourism in a non-consumptive manner (Duffus and Dearden 1990; Gössling 1999; Stronza et al. 2019). However, as more people have sought experiences in nature and encounters with wildlife, the risks of overcrowding sensitive habitats and disturbing the vital behavior patterns of the species living in those habitats have mushroomed. Without intervention, upsurges in outdoor recreation (e.g., Bowker et al. 2012; Mitrovich et al. 2020) and visitation to California's natural areas (National Park Service 2020; Pendleton and Kildow 2006) will negatively impact wildlife through human disturbance (Larson et al. 2016; Lucas 2020; Steven et al. 2011). Can communities in California preserve the benefits of ecotourism and other human recreational activities while mitigating some of their more adverse consequences on coastal wildlife?

Visitors to California's coastal areas seek opportunities to view and photograph marine wildlife specifically, or they may incidentally encounter marine wildlife while partaking in other activities (e.g., hiking, kayaking, boating, stand-up paddleboarding, scuba diving, fishing, tide-pooling, sightseeing, exercising, picnicking). For locals and visitors alike, seeing or photographing a bird taking flight or catching the gaze of a seal can be an exhilarating 
experience and a treasured connection with nature. The skyrocketing popularity of posting wildlife encounters (e.g., wildlife selfies) on social media can drive visitors to engage in risky close approaches to obtain the perfect photograph (Ward-Paige 2016; Cherry et al. 2018; Pagel et al. 2020). But the human experience - the risks and rewards of wildlife encounters - does not always end well for the animals.

Visible changes in an animal's behavior can signal the disruption caused by close approaches by humans (Fig. 1), but some species can experience an elevated heart rate (stress response) without overt behavioral change (MacArthur et al. 1982; Coetzee and Chown 2016). Frequent and chronic disruption leads to reduced fitness, disrupts vital and sensitive activities - feeding, breeding, nursing, resting, migrating - and contributes to negative consequences (e.g., energetic stress, separation of mothers and young, interference in parental care, habituation, site abandonment), all of which can impact survival and population viability (Spaul and Heath 2016; Monti et al. 2018; Perona et al. 2019; Doherty et al. 2021). Whether intentional or inadvertent, human disturbance alters an animal's normal behavior, carries a physiological cost, and can produce cascading, ecosystem-wide consequences (Klein et al. 1995; Heil et al. 2007; Gaynor et al. 2018; Suraci et al. 2019; Doherty et al. 2021).

The COVID-19 pandemic has added to the complexity and urgency of the wildlifedisturbance issue by triggering unprecedented and unexpected shifts in outdoor recreation activities, especially in coastal areas. The outdoor gear industry saw a $56 \%$ sales jump in paddlesport equipment and a 31\% increase in camping equipment in June 2020 over the same period in 2019 (NPD Group 2020). Highlighted on social media as a COVID-safe activity, tide pooling in locations like Pillar Point near San Francisco exploded, with hundreds of visitors crowding these areas during low tides (Marshall-Chalmers 2021). Despite limitations on daily entries, reduced services, and timed reservations, visitation boomed at some national parks through summer 2020 (Rott 2020). This upsurge in outdoor recreation, fueled in part by people with little or no experience in nature and lacking awareness of Leave No Trace principles (Marion and Reid 2001), likely increased the occurrences of wildlife disturbance and habitat degradation in 2020. COVID-19 restrictions further exacerbated the problem of wildlife disturbance by curtailing formal interpretive programs at state and federal parks and virtually eliminated in-person delivery of information to recreationists about appropriate behavior around wildlife.
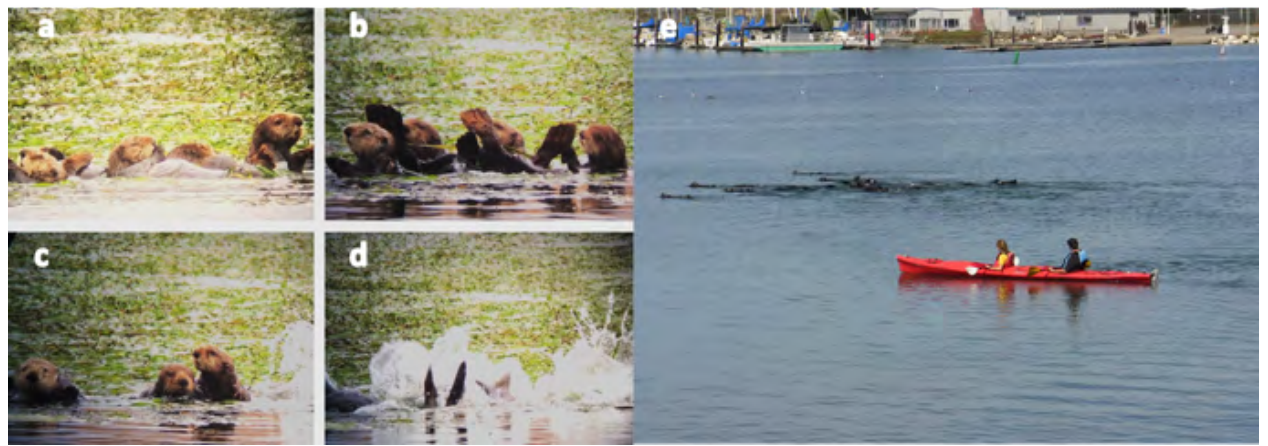

Figure 1. Examples of visible changes to sea otter behavior due to human disturbance. (A-D) A time series of 4 images captured through a high-powered spotting scope showing a group of sea otters being disturbed by an approaching kayaker. (A), the group is resting, (B) the otters are alert, (C) the animals are agitated and one dove, and (D) the entire group dove. (E) A large raft of sea otters fleeing from a pursuing kayak. 
Human disturbance of wildlife is a global issue that affects innumerable species (Larson et al. 2016). A growing body of research into the consequences of human-caused disturbance has revealed that some species or taxonomic groups are more vulnerable to disturbance and are more frequently disturbed. Additionally, species that garner more public interest can generate funding to study wildlife-disturbance issues. Marine mammals comprise charismatic species that have suffered well-documented incidences and costs of anthropogenic disturbance. Phocids, or true seals, are among the best-studied marine mammals with respect to human disturbance. Documented impacts range from visually apparent reactions like behavioral changes (e.g., van Polanen Petel et al. 2008) and site abandonment (e.g., Kenyon 1972) to less obvious internal physiological changes, such as increased heart rate (e.g., Karpovich et al. 2015). A study of harbor seals (Phoca vitulina) at Bolinas Lagoon in Marin County, California, found that humans disturbed seals on $71 \%$ of the days that researchers monitored them and that $72 \%$ of disturbances caused seals to disperse, resulting in short-term $(28 \pm 20.8 \mathrm{~min})$ site abandonment (Allen et al. 1984). A study spanning three decades by Becker et al. (2011) at nearby Drakes Estero, also in Marin County, found that disturbance caused by mariculture activities resulted in long-term spatial displacement of breeding and pupping harbor seals.

Scientists have documented harmful effects from human disturbance in a myriad of other marine mammal species. For example, changes in activity budgets and increased energetic costs to killer whales (Orcinus orca) in response to boat traffic (Williams et al. 2006), behavioral changes of gray whales (Eschrichtius robustus) in response to anthropogenic noise (Moore and Clarke 2002), reduced foraging activity of bottlenose dolphins (Tursiops trunca$t u s$ ) in response to vessel presence (Pirotta et al. 2015), and increased behavioral responses and associated energetic costs of southern sea otters (Enhydra lutris nereis) in response to various anthropogenic stimuli (Barrett 2019). Significant effort has gone into mitigating disturbance to marine mammals, including federal legislation such as the Marine Mammal Protection Act (1972), regional and local restrictions such as seasonal and geographic closures and distance regulations (e.g., Young et al. 2014), and outreach programs such as Team OCEAN (Gunvalson 2011), with variable, but generally insufficient, effectiveness.

The public is often less aware of the effects repeated disturbances have on seabirds. Disturbance to seabirds is harmful and is particularly pronounced during the nesting season (e.g., Beale and Monaghan 2004). Human disturbance of nesting activity can lead to nest abandonment, dislodging of eggs and chicks from nest sites, predators feeding on eggs and chicks, exposure of eggs and chicks to heat or cold, and drowning of chicks when forced to fledge early. Specifically, human disturbance has been shown to reduce reproductive success in surface-nesting seabirds such as brown pelicans (Pelecanus occidentalis; Anderson and Keith 1980; Anderson 1988) and common murres (Uria aalge; Rojek et al. 2007); burrow-nesters such as Cassin's auklets (Ptychoramphus aleuticus; Albores-Barajas and Soldatini 2011); rocky-shoreline-nesting birds such as European oystercatchers (Haematopus ostralegus; Verhulst et al. 2001); and beach-nesting birds such as western snowy plovers (Charadrius nivosus nivosus; Lafferty 2001; Ruhlen at al. 2003).

Some studies have even documented impacts of human disturbance on invertebrate communities within rocky intertidal habitats in California (e.g., Lucas and Smith 2016); wildlife that often are not considered by the public as they flock to shorelines and parks in droves for recreational pursuits. Some invertebrates may shift their distribution within the intertidal habitat (e.g., Lucrezi et al. 2009) and other populations may be artificially elevated, 
fostered by visitor food scraps (e.g., Steiner and Leatherman 1981; Schlacher et al. 2011), which in turn may increase intraguild predation. Recreational harvesting of mussels and other habitat-forming species could weaken the intertidal habitat (Marshall-Chalmers 2021).

Although several laws prohibit the disturbance of wildlife, such as the Marine Mammal Protection Act, the Endangered Species Act, and the Migratory Bird Treaty Act, enforcement personnel cannot monitor the millions of users spread along the California coastline. The legal definitions of what constitutes wildlife disturbance are vague, open to interpretation, and difficult for the general public to understand. As a result, resource managers have primarily defaulted to requiring or recommending minimum distance guidelines for avoiding wildlife disturbance. Though these distance guidelines are well-intentioned, research indicates that compliance can be low (e.g., Johnson and Acevedo-Gutiérrez 2007; Acevedo-Gutiérrez et al. 2011), the recommendations may not be adequate for particular species or taxa (e.g., Beale and Monaghan 2004; Young et al. 2014), and enforcement can be difficult or impossible. Additionally, visitors' perceptions of acceptable approach distances for wildlife rarely match the established distance guidelines or regulations (e.g., Taylor and Knight 2003). In most cases, individuals intend no harm and do not believe that their actions will alter wildlife behavior and cause undesirable effects (e.g., Slater et al. 2019); however, once a disturbance occurs, many recreationists will attempt to shift blame for wildlife disturbance to others rather than accepting personal responsibility for their conduct (e.g., Taylor and Knight 2003).

To improve compliance with guidelines, agencies and groups have employed signs as a tool for obtaining compliance with wildlife protection laws and guidelines and for reducing wildlife disturbance; however, little evidence exists that signs can produce immediate or lasting behavior change (e.g., Acevedo-Gutiérrez et al. 2011). Governmental and nongovernmental entities (e.g., National Oceanic and Atmospheric Administration, Sea Otter Savvy) have also implemented localized and taxa-specific measures to minimize disturbance to coastal wildlife in California. Examples of these initiatives and taglines include Whale SENSE, No Selfies with Seals, SeaLife Stewards, and Respect the Nap. While some of these actions have yielded reductions in disturbance (Gunvalson 2011; Allbrook and Quinn 2020), messaging within the various programs about approach distances and avoidance measures has often conflicted (Fig. 2), and most actions have not halted the increasing trajectory of disturbance or created lasting behavioral change in coastal visitors. In recognition of these issues, wildlife-disturbance experts along the California coast began coordinating their efforts to reduce wildlife disturbance by attending the first California Coastal Wildlife Disturbance Symposium (CCWDS) in 2015. The CCWDS brought together staff from government, NGOs, and local businesses to discuss the relative effectiveness of diverse efforts to mitigate human-caused disturbance to coastal wildlife. At that first CCWDS, the idea of developing a statewide campaign to address disturbance to marine wildlife in California emerged during a small breakout session. The group identified that while localized efforts to curtail coastal wildlife disturbance had occurred, no unified statewide effort existed in California to tackle the problem. Subsequently, the group recruited a diverse coalition of experts to advise on the development of a formal initiative, the Respect Wildlife Campaign (RWC), that would generate consistent science-based messaging across multiple communications platforms and define, establish, and instill a norm of responsible behavior among people in the presence of marine wildlife.

Over the past five years, an RWC working group has met regularly to work toward the development and implementation of the RWC. The RWC approach is unique because the 


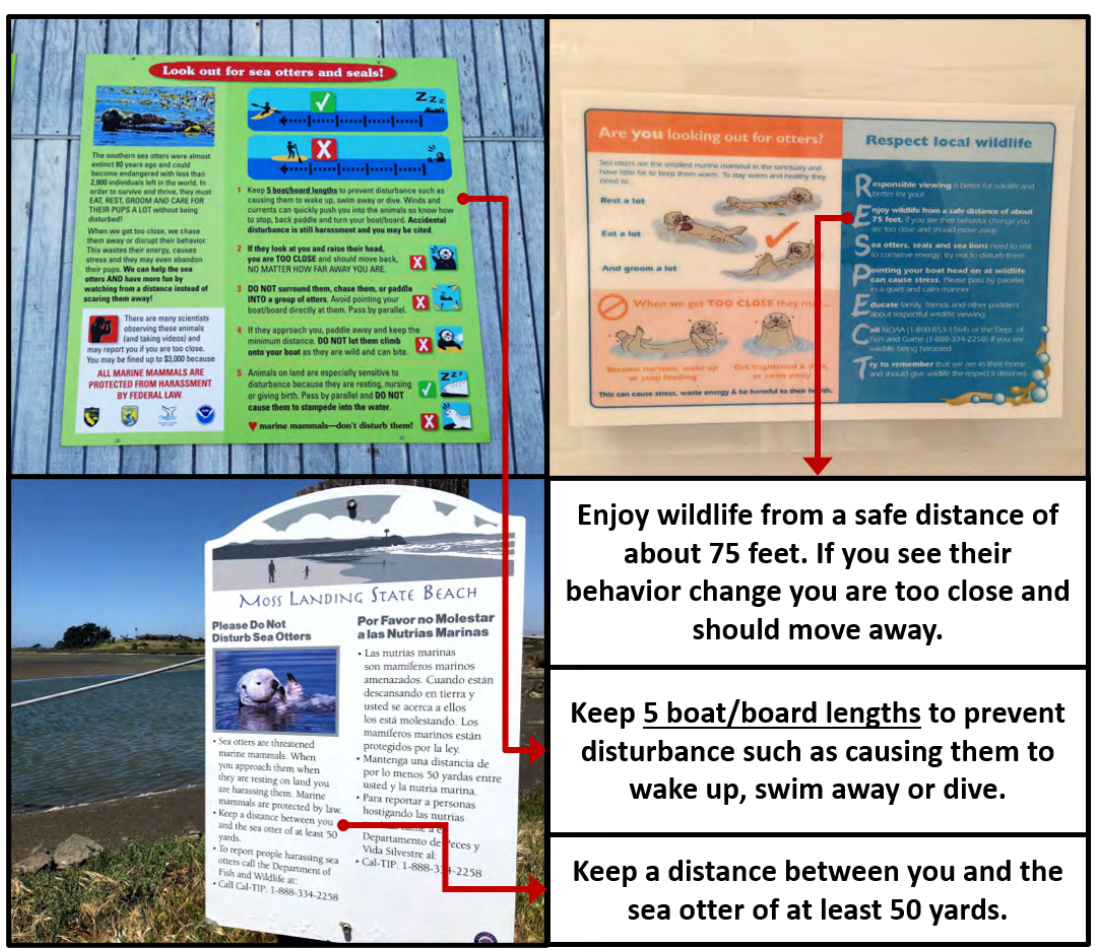

Figure 2. Examples of signs posted in Moss Landing, California, that provide conflicting guidance about the appropriate distance for paddlers to avoid disturbing sea otters.

core collaborating group includes meshes information from biologists, interpreters, resource managers, and social scientists from governmental agencies and non-governmental organizations with extensive input from local marine-recreation business operators, communication and marketing experts, and other stakeholders (see Table 1). The RWC has maintained its connection to the CCWDS, which has become a valued forum for organizers and attendees to share ideas, celebrate innovation, and learn from each other's successes and failures. During the COVID-19 pandemic, the CCWDS transitioned to a virtual platform in 2020 and broadened its reach to more than 130 attendees from 30 agencies, organizations, and other entities in California and other states. This experience brought home the power of virtual platforms for reaching new audiences and creating new partnerships. Although social media can exacerbate wildlife disturbance by showing people engaged in improper behavior around wildlife, the RWC sees opportunities to alleviate human impacts using those same platforms.

A fundamental lesson from the past five years of RWC collaboration is that changing human behavior is a complex endeavor. While it is clear that wildlife benefits the most when groups work in partnership to create unified, consistent messaging, the challenge of reaching diverse audiences with messages that will inspire and endure persists. The RWC aspires to plant seeds of awareness that will touch upon people's core beliefs or educate in such a way that respectful wildlife engagement becomes a part of those core beliefs. The RWC messaging will use the concept of conflict transformation to deconstruct embedded beliefs and behavior toward wildlife and realize constructive change (Lederach and Maiese 
Table 1. Core collaborators in the California statewide Respect Wildlife Campaign.

\begin{tabular}{cc}
\hline Core Collaborator & Entity Type \\
\hline Audubon California & nonprofit organization \\
Bureau of Land Management & federal agency \\
California Department of Fish and Wildlife & state agency \\
MPA Collaborative Network & sponsored organization \\
California State Parks & state agency \\
Defenders of Wildlife & nonprofit organization \\
Monterey Bay Kayaks & for profit \\
Office of National Marine Sanctuaries & federal agency \\
National Park Service & federal agency \\
Oceans Unmanned & federal agency \\
Save the Whales & nonprofit organization \\
Sea Otter Savvy & nonprofit organization \\
U.S. Fish and Wildlife Service & nonprofit organization \\
\hline
\end{tabular}

2003; Zimmermann et al. 2020). A conflict transformation approach will reframe the conflict (i.e., wildlife disturbance) from a problem to an opportunity, a shift in perspective that will build relationships and engender improved behavior (i.e., respect) toward wildlife. All RWC messaging will seek to transform wildlife viewers who inadvertently or intentionally harm wildlife into advocates for responsible wildlife viewing (Ardoin et al. 2015).

To evaluate the RWC's effectiveness and contribute to the body of knowledge on how to change human behavior to protect coastal wildlife, social scientists within the RWC collaborative group will employ an arsenal of survey instruments to collect data over five years on a range of campaign actions. Social media metrics, survey analyses, interviews, field monitoring, and other tools will document the efficacy of interpretive information, education and outreach initiatives, and social media ads in an effort to identify how human behavior changes with respect to coastal wildlife disturbance. In turn, clarifying people's perceptions, values, and expectations regarding marine and coastal wildlife, ecosystems, and habitats will help inform and guide the ongoing refinement of outreach and communication strategies. From a management perspective, the RWC will encourage improved public compliance with wildlife protection laws, regulations, and guidelines. To solidify and reinforce its messaging, the RWC will publicize information about measurable decreases in the incidence of wildlife disturbance and any resulting short- or long-term positive individual and population-level effects for coastal species.

With visitation to natural areas increasing and novices attempting new outdoor recreation activities, the need for clear, consistent messaging to protect wildlife and fragile ecosystems across parks, beaches, and open spaces in California will only intensify (Ardoin et al. 2015). Whether or not people engage in wildlife-watching activities, they have an impact on wildlife. Mitigating the disruption of wildlife, particularly during vulnerable life-history stages, is critical for species conservation. By continuing to operate through multi-agency, multi-organization task groups, the RWC will facilitate better education and 
outreach with clearer objectives and messaging, foster a new ethic of respect for wildlife in all people who live in or visit coastal California, and serve as a model for other programs within California, across the United States, and around the globe.

\section{ACKNOWLEDGMENTS}

The authors of this essay are greatly indebted to the individuals who have volunteered their time and expertise to help develop and support the Respect Wildlife Campaign during the last 5 years. We would like to especially thank our current core collaborators: C. O'Brien, I. Irving, C. Allison, N. Palma, P. Hobi, V. Monroe, A. Heeren, and K. Darr. Thanks also are due to C. Skinder, S. Tezak, M. Sidenstecker, A. Amerson, M. Pickett, B. Taggart, D. Ledig, S. Furey, E. Richter, J. Foca, L. Emanuelson, K. Spencer, S. Kathey, P Clark-Gray, S. Bachman, T. Kiechkhefer, A. Wood, G. Bottitta, J. Ugoretz, L. Henkel, L. Carswell, M. Staedler, A. McConnell, and R. Gerstenslager. We would also like to thank the California Ocean Protection Council for funding, and Oceans Unmanned for fiscal sponsorship. Additionally, personnel from Sea Otter Savvy, the Seabird Protection Network, the Monterey Bay Aquarium, Moss Landing Marine Labs, and California State Parks have been instrumental in the planning and execution of the annual CCWDS by providing various venues for connecting, collaborating, and strategizing, as well as much-needed humor! Finally, we would like to thank our law enforcement partners from the U.S. Department of Justice, California Department of Fish and Wildlife, National Oceanic and Atmospheric Administration, California State Parks, and the U.S. Fish and Wildlife Service for their efforts to protect wildlife from disturbance and for providing information on how best to document and report egregious incidences of wildlife disturbance.

\section{LITERATURE CITED}

Acevedo-Gutiérrez, A., L. Acevedo, O. Belonovich, and L. Boren. 2011. How effective are posted signs to regulate tourism? An example with New Zealand fur seals. Tourism in Marine Environments 7(1):39-41.

Allbrook, D. L., and J. L. Quinn. 2020. The effectiveness of regulatory signs in controlling human behaviour and northern gannet (Morus bassanus) disturbance during breeding: an experimental test. Journal for Nature Conservation 58:125915.

Allen, S. G., D. G. Ainley, G. W. Page, and C. A. Ribic. 1984. The effect of disturbance on harbor seal haul out patterns at Bolinas Lagoon, California. Fishery Bulletin $82: 493-500$.

Anderson, D. W., and J. O. Keith. 1980. The human influence on seabird nesting success: conservation implications. Biological Conservation 18:65-80.

Anderson, D. W. 1988. Dose-response relationship between human disturbance and brown pelican breeding success. Wildlife Society Bulletin 16:339-345.

Ardoin, N. M., M. Wheaton, A. W. Bowers, C. A. Hunt, and W. H. Durham. 2015. Naturebased tourism's impact on environmental knowledge, attitudes, and behavior: a review and analysis of the literature and potential future research. Journal of Sustainable Tourism 23(6):838-858.

Balmford, A., J. M. Green, M. Anderson, J. Beresford, C. Huang, R. Naidoo, M. Walpole, and A. Manica. 2015. Walk on the wild side: estimating the global magnitude of visits to protected areas. PLoS Biology 13(2):e1002074. 
Barrett, H. E. 2019. The energetic cost of anthropogenic disturbance on the southern sea otter (Enhydra lutris nereis). Thesis, San Jose State University, San Jose, CA, USA.

Beale, C. M., and P. Monaghan. 2004. Human disturbance: people as predation-free predators? Journal of Applied Ecology 41(2):335-343.

Becker, B. H., D. T. Press, and S. G. Allen. 2011. Evidence for long-term spatial displacement of breeding and pupping harbour seals by shellfish aquaculture over three decades. Aquatic Conservation: Marine and Freshwater Ecosystems 21(3):247260.

Bowker, J. M., A. E. Askew, H. K. Cordell, C. J. Betz, S. J. Zarnoch, and L. Seymour. 2012. Outdoor recreation participation in the United States-projections to 2060: a technical document supporting the Forest Service 2010 RPA Assessment. General Technical Report SRS-160. U.S. Department of Agriculture Forest Service, Southern Research Station, Asheville, NC, USA.

Cherry, C., K. M. Leong, R. Wallen, and D. Buttke. 2018. Risk-enhancing behaviors associated with human injuries from bison encounters at Yellowstone National Park, 2000-2015. One Health 6:1-6.

Coetzee, B. W., and S. L. Chown. 2016. A meta-analysis of human disturbance impacts on Antarctic wildlife. Biological Reviews 91(3):578-596.

Doherty, T. S., G. C. Hays, and D. A. Driscoll. 2021. Human disturbance causes widespread disruption of animal movement. Nature Ecology \& Evolution 5(4):513-519.

Duffus, D. A., and P. Dearden. 1990. Non-consumptive wildlife-oriented recreation: a conceptual framework. Biological Conservation 53(3):213-231.

Gaynor, K. M., C. E. Hojnowski, N. H. Carter, and J. S. Brashares. 2018. The influence of human disturbance on wildlife nocturnality. Science 360:1232-1235.

Gössling, S. 1999. Ecotourism: a means to safeguard biodiversity and ecosystem functions? Ecological Economics 29:303-320.

Gunvalson, M. M. 2011. Reducing disturbances to marine mammals by kayakers in the Monterey Bay. Thesis, San Jose State University, San Jose, CA, USA.

Heil, L., E. Fernández-Juricic, D. Renison, A. M. Cingolani, and D. T. Blumstein. 2007. Avian responses to tourism in the biogeographically isolated high Córdoba Mountains, Argentina. Biodiversity and Conservation 16:1009-1026.

Johnson, A., and A. Acevedo-Gutiérrez. 2007. Regulation compliance by vessels and disturbance of harbour seals (Phoca vitulina). Canadian Journal of Zoology 85(2):290-294.

Karpovich, S. A., J. P Skinner, J. E. Mondragon, and G. M. Blundell. 2015. Combined physiological and behavioral observations to assess the influence of vessel encounters on harbor seals in glacial fjords of southeast Alaska. Journal of Experimental Marine Biology and Ecology 473:110-120.

Kenyon, K. W. 1972. Man versus the monk seal. Journal of Mammalogy 53:687-696.

Klein, M. L., S. R. Humphrey, and H. F. Percival. 1995. Effects of ecotourism on distribution of waterbirds in a wildlife refuge. Conservation Biology 9:1454-1465.

Larson, C. L., S. E. Reed, A. M. Merenlender, and K. R. Crooks. 2016. Effects of recreation on animals revealed as widespread through a global systematic review. PloS ONE 11(12):e0167259.

Lederach, J. P., and M. Maiese. 2003. Conflict transformation, beyond intractability. G. Burgess and H. Burgess, editors. Conflict Information Consortium, University of 
Colorado, Boulder, CO, USA. Excerpts published online in October 2003; Available from: https://www.beyondintractability.org/essay/transformation (Accessed 19 December 2020)

Lucas, B. J., and J. R. Smith. 2016. Alterations in human visitation patterns and behaviors in southern California rocky intertidal ecosystems over two-decades following increased management efforts. Ocean \& Coastal Management 121:128-140.

Lucas, E. 2020. Recreation-related disturbance to wildlife in California-better planning for and management of recreation are vital to conserve wildlife in protected areas where recreation occurs. California Fish and Wildlife, Recreation Special Issue 29-51.

Lucrezi, S., T. A. Schlacher, and S. Walker. 2009. Monitoring human impacts on sandy shore ecosystems: a test of ghost crabs (Ocypode spp.) as biological indicators on an urban beach. Environmental Monitoring and Assessment 152(1):413-424.

MacArthur, R. A., V. Geist, and R. H. Johnston. 1982. Cardiac and behavioral responses of mountain sheep to human disturbance. Journal of Wildlife Management 46(2):351-358.

Marion, J. L., and S. E. Reid. 2001. Development of the U.S. Leave No Trace program: an historical perspective. Available from: https://web.archive.org/ web/20060902170134/http://www.lnt.org/about/LNTHistoryPaper.pdf (Accessed 31 December 2020)

Marshall-Chalmers, A. 2021. Packed at Pillar Point: huge crowds are harvesting mussels and other invertebrates. Published 12 January 2021 in Bay Nature. Available from: https://baynature.org/2021/01/12/packed-at-pillar-point (Accessed 14 May 2021)

Mitrovich, M., C. L. Larson, K. Barrows, M. Beck, and R. Unger. 2020. Balancing conservation and recreation. California Fish and Wildlife Journal, Recreation Special Issue 11-28.

Monti, F., O. Duriez, J. M. Dominici, A. Sforzi, A. Robert, L. Fusani, and D. Grémillet. 2018. The price of success: integrative long-term study reveals ecotourism impacts on a flagship species at a UNESCO site. Animal Conservation 21(6):448458.

Moore, S. E., and J. T. Clarke. 2002. Potential impacts of offshore human activities on gray whales (Eschrichtius robustus). Journal of Cetacean Research and Management 4(1):19-25.

Murray, A., E. Garrud, I. Ender, K. Lee-Brooks, R. Atkins, R. Lynam, K. Arnold, C. Roberts, J. Hawkins, and G. Stevens. 2020. Protecting the million-dollar mantas; creating an evidence-based code of conduct for manta ray tourism interactions. Journal of Ecotourism 19(2):132-147.

NPD Group. 2020. American Outdoors: Consumers are flocking to these five activities [Feature Article]. Available from: https:/www.npd.com/wps/portal/npd/us/news/ thought-leadership/2020/consumers-are-flocking-to-these-5-activities/ (Accessed 19 December 2020)

National Park Service. 2020. National park visitation tops 327 million in 2019 [News release]. Available from: https://www.nps.gov/orgs/1207/2019-visitation-numbers. htm (Accessed 19 December 2020)

Pagel, C. D., M. B. Orams, and M. Lück. 2020. \#biteMe: Considering the potential influence of social media on in-water encounters with marine wildlife. Tourism in 
Marine Environments 15:249-258.

Perona, A. M., V. Urios, and P. López-López. 2019. Holidays? Not for all. Eagles have larger home ranges on holidays as a consequence of human disturbance. Biological Conservation 231:59-66.

Pirotta, E., N. D. Merchant, P. M. Thompson, T. R. Barton, and D. Lusseau. 2015. Quantifying the effect of boat disturbance on bottlenose dolphin foraging activity. Biological Conservation 181:82-89.

Pendleton, L., and J. Kildow. 2006. The non-market value of beach recreation in California. Shore and Beach 74(2):34-37.

Rott, N. 2020. 'We Had to Get Out': Despite the risks, business is booming at national parks. Published 11 August 112020 at NPR. Available at: https://www.npr. org/2020/08/11/900270344/we-had-to-get-out-despite-the-risks-business-isbooming-at-national-parks (Accessed 14 May 2021)

Schlacher, T. A., R. De Jager and T. Nielsen. 2011. Vegetation and ghost crabs in coastal dunes as indicators of putative stressors from tourism. Ecological Indicators 11(2):284-294.

Slater, C., G. Cam, Y. Qi, Y. Liu, P. J. Guay, and M. A.Weston. 2019. Camera shy? Motivations, attitudes and beliefs of bird photographers and species-specific avian responses to their activities. Biological Conservation 237:327-337.

Spaul, R. J., and J. A. Heath. 2016. Nonmotorized recreation and motorized recreation in shrub-steppe habitats affects behavior and reproduction of golden eagles (Aquila chrysaetos). Ecology and Evolution 6:803-8049.

Steiner, A. J., and S. P. Leatherman. 1981. Recreational impacts on the distribution of ghost crabs Ocypode quadrata Fab. Biological Conservation 20:111-122.

Steven, R., C. Pickering, and J.G. Castley. 2011. A review of the impacts of nature-based recreation on birds. Journal of Environmental Management 92(10):2287-2294.

Stronza, A. L., C. A. Hunt, and L. A. Fitzgerald. 2019. Ecotourism for Conservation? Annual Review of Environment and Resources 44(1):229-253.

Suraci, J. P., M. Clinchy, L. Y. Zanette, and C. C. Wilmers. 2019. Fear of humans as apex predators has landscape-scale impacts from mountain lions to mice. Ecology Letters 22(10):1578-1586.

Taylor, A. R., and R. L. Knight. 2003. Wildlife responses to recreation and associated visitor perceptions. Ecological Applications 13(4):951-963.

van Polanen Petel, T., M. Giese, and M. Hindell. 2008. A preliminary investigation of the effect of repeated pedestrian approaches to Weddell seals (Leptonychotes weddellii). Applied Animal Behaviour Science 112:205-211.

Verhulst, S., K. Oosterbeek, and B. J. Ens. 2001. Experimental evidence for effects of human disturbance on foraging and parental care in oystercatchers. Biological Conservation 101(3):375-380.

Ward-Paige, C. A. 2016. Even scientists take selfies with wild animals. Here's why they shouldn't. The Conversation. 28 June. Available from: https://theconversation.com/even-scientists-take-selfies-with-wild-animals-heres-why-theyshouldnt-61252 (Accessed 19 December 2020)

Williams, R., D. Lusseau, and P. S. Hammond. 2006. Estimating relative energetic costs of human disturbance to killer whales (Orcinus orca). Biological Conservation 133(3):301-311. 
Young, C., S. M. Gende, and J. Harvey. 2014. Effects of vessels on harbor seals in Glacier Bay National Park. Tourism in Marine Environments 10(1-2):5-20.

Zimmermann, A., B. McQuinn, and D. W. Macdonald. 2020. Levels of conflict over wildlife: Understanding and addressing the right problem. Conservation Science and Practice 2(10):e259.

Submitted 31 December 2020

Accepted 27 April 2021

Associate Editor was V. Monroe 